\title{
Analisis beban pendingin cold storage PT. Sari Tuna Makmur Aertembaga Bitung, Sulawesi Utara
}

\author{
Cooling load analysis of cold storage at PT Sari Tuna makmur, Aertembaga, Bitung, \\ Sulawesi Utara \\ Andie MurtonO*, PATRICE N.I. KALANGi dan FrANGKY E. KAPARANG \\ Program Studi Pemanfaatan Sumberdaya Perikanan, Fakultas Perikanan dan Ilmu Kelautan, \\ Universitas Sam Ratulangi, Manado 95115
}

\begin{abstract}
Fish is an organic material that mostly composed of enzymes and proteins. These substances are a very good mediaculture for spoilage bacteria. After captured, fish should be given a special treatment to inhibit the growth of bacteria. One way can be done is to put the fish in a cold room or container, a cold storage. The purposes of this research were 1) to calculate the capacity of cold storage; and 2) to calculate the amount of cooling load of the cold storage at PT Sari Tuna Makmur. The cold storage capacity according to that calculation was 123,5 tons but the cold storage could accomodates frozen fish up to 120 tons. Cooling engine performed automatically defrost processes 4 times a day for half an hour between each process. The operational time (running time) of the cooling engine in one day is 22 hours. The total needed cooling load was 82,717.32 Btu/hr.
\end{abstract}

Keywords: tuna, capacity, cooling load, cold storage, Bitung

\begin{abstract}
ABSTRAK
Ikan adalah bahan organik yang sebagian besar sel penyusunannya terdiri atas enzim dan protein. Kedua zat ini merupakan media perkembang-biakan yang sangat baik bagi bakteri pembusuk. Setelah ditangkap, ikan harus diberi perlakuan tertentu untuk menghambat pertumbuhan bakteri tersebut. Salah satu cara yang dapat dilakukan adalah meletakkan ikan pada wadah atau ruang yang dingin yaitu cold storage. Tujuan penelitian adalah 1) menghitung besar kapasitas penyimpanan cold storage; 2) menghitung besar beban pendingin cold storage PT. Sari Tuna Makmur. Kapasitas cold storage sesuai perhitungan dalah 123,5 ton tetapi yang digunakan hanya sampai 120 ton. Mesin pendingin melakukan 4 kali defrost secara otomat dalam sehari, masing-masing tiap setengah jam. Lama waktu mesin pendingin beroperasi (running time) dalam 1 hari adalah 22 jam. Total beban pendingin yang dibutuhkan adalah $82.717,32 \mathrm{Btu} / \mathrm{hr}$.
\end{abstract}

Kata-kata kunci: tuna, kapasitas, beban pendingin, cold storage, Bitung

\section{PENDAHULUAN}

Manusia sejak lama berusaha untuk mendapatkan cara agar dapat menyimpan makanan yang dapat bertahan lebih lama. Berbagai cara yang telah dilakukan di antaranya adalah pengasinan, pengeringan, pengasapan, pemberian rempah-rempah dan pendinginan. Di antara cara-cara pengawetan tersebut ternyata dengan cara didinginkan dianggap paling baik karena bahan makanan/ikan yang telah didinginkan akan tetap segar dan tidak akan

\footnotetext{
*Penulis untuk penyuratan; email:
} andie_murtono@yahoo.com mengalami perubahan rasa, warna dan aromanya, di samping itu segala aktivitas yang menyebabkan pembusukan akan terhenti sehingga bahan makanan/ikan yang didinginkan akan dapat tahan lebih lama lagi (Hartanto,1984).

Lebih khusus pada ikan, ada bermacam-macam jenis ikan yang dapat di jumpai, misalnya tuna, cakalang, tongkol, deho, layang, tude dan lain-lain, yang kesemuanya mempunyai nilai ekonomis yang tinggi dengan kandungan gizi yang tinggi pula. Hal ini sangat membantu bagi manusia dalam peningkatan kesejahteraan keluarga ataupun memenuhi akan kebutuhan protein yang sangat 
berguna dalam perkembangan tubuh manusia. Untuk daerah Sulawesi Utara yang dikelilingi oleh lautan, hasil perikanannya cukup besar, ada yang dikonsumsi masyarakat Sulawesi Utara dan ada juga yag dikirim ke luar daerah bahkan sampai di ekspor ke luar Negeri. Dengan semakin majunya teknologi penangkapan ikan, maka kuantitas ikan yang ditangkap semakin meningkat pula. Dari hasil tangkapan ini, sebagian dapat segera dijual pada konsumen tetapi ada sebagian lagi yang belum sempat dipasarkan.

Mesin pendingin saat ini semakin banyak digunakan seiring dengan kemajuan teknologi dan kebutuhan konsumen dalam mengawetkan makanan dan membekukan ikan. Umumnya penggunaan mesin pendingin digunakan dalam industri perikanan, baik di darat maupun di laut karena memiliki peran yang sangat penting dalam mempertahankan mutu hasil tangkapan dan menjaga kualitas kesegaran ikan.

Ikan adalah bahan biologis yang apabila tidak memperoleh perlakuan tertentu setelah ditangkap dan diangkat dari air, maka ia akan mengalami penurunan kualitas ke arah membusuk. Oleh karena itu perlu diadakan suatu teknik yang dapat dilakukan untuk mempertahankan kesegaran ikan agar supaya tetap awet dan layak dikonsumsi. Untuk cara yang lebih efisien, praktis dan rasa ikan tetap seperti semula maka digunakan cold storage untuk mempertahankan kualitas ikan, sehingga bakteri yang menyebabkan penurunan mutu ikan dapat terhambat perkembangannya dan ikan menjadi tidak cepat busuk (Afrianto, dan Liviawaty, 1992).

Apabila dalam pengoperasiannya mesin pendingin tidak dilakukan sesuai prosedur dan tahapan-tahapan kerjanya, maka akan timbul kerusakan. Hal inilah yang perlu diperhatikan oleh seorang teknisi dalam mengoperasikan mesin pendingin. Tujuan penelitian ini adalah: (1) menghitung besar kapasitas penyimpanan cold storage; (2) menghi-tung besar beban pendingin cold storage PT. Sari Tuna Makmur Bitung. Penelitian ini dilaksanakan selama Desember 2014 sampai Februari 2015.

\section{METODE PENELITIAN}

Penelitian ini menggunakan metode deskriptif. Menurut Djojodiharjo (1987), metode deskriptif yang bersifat eksploratif bertujuan untuk menggambarkan keadaan atau status fenomena, pada umumnya penelitian ini merupakan penelitian non hipotesis sehingga dalam langkah penelitiannya tidak perlu merumuskan hipotesis.

Data yang dikumpulkan dalam penelitian ini meliputi data primer dan data sekunder. Data primer yaitu data yang diambil langsung pada saat mesin beroperasi. Wawancara dilakukan kepada Kepala Instalasi Mesin pendingin dan karyawan bagian mesin pendingin berkaitan dengan pengoperasian dan perawatan mesin pendingin. Selanjutnya data sekunder diperoleh dari jurnal harian mesin pendingin, serta studi pustaka mengenai mesin pendingin cold storage yang lebih khusus. Data disusun dalam bentuk tabel dan digambarkan dalam bentuk grafik. Beban-beban pendingin cold storage digambarkan dalam bentuk grafik sesuai kondisi yang ditampilkan.

\section{HASIL DAN PEMBAHASAN}

\section{Perhitungan kapasitas cold storage}

Perhitungan kapasitas cold storage ini menggunakan metode perhitungan selisih volume, di mana hasil akhirnya berupa jumlah dos yang dapat ditampung dalam cold storage dikali berat tiap dos yaitu $10 \mathrm{~kg}$. Sehingga didapat kapasitas cold storage sesuai hasil perhitungan (Holman, 1986). Untuk jelasnya dapat dilihat pada Gambar 1 dan perhitungan-perhitungan berikut.

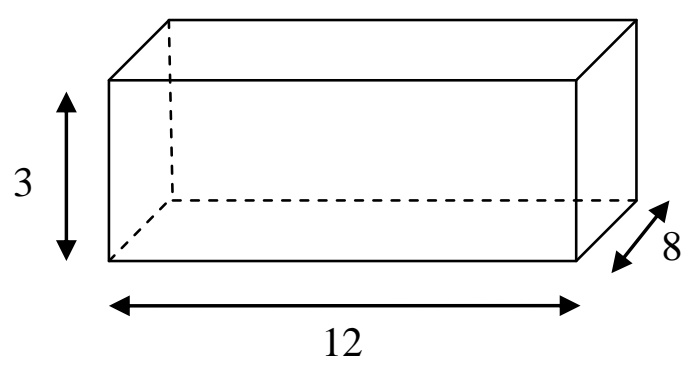

Gambar 1. Denah cold storage PT. Sari Tuna Makmur

Volume cold storage (keseluruhan dengan ukuran seperti di Gbr. 1) adalah $288 \mathrm{~m}^{3}$. Sedangkan volume bagian cold storage untuk konstruksi dan peralatan (tidak untuk menampung dos) masing-masing adalah sebagai berikut:

Ante room, bagian yang masuk ke ruang cold storage, memiliki ukuran panjang, lebar dan tinggi secara berurut 1,2 , dan $3 \mathrm{~m}$, maka volumenya adalah $6 \mathrm{~m}^{3}$. Fan evaporator memiliki 2 kipas yang digabung dalam 1 unit pada ruang berukuran $\mathrm{p}=3$ 
$\mathrm{m}, 1=1,3 \mathrm{~m}$, dan $\mathrm{t}=1 \mathrm{~m}$ dengan volume sebesar $3,9 \mathrm{~m}^{3}$.

Ruang kosong pada sisi atas dan bawah cold storage. Ruang ini berfungsi untuk memperlancar pergerakan udara dingin dalam ruangan Jarak dari bagian atap ke permukaan dos yang paling atas 0,1 m. Begitupun dengan jarak dari lantai ke permukaan dos yang paling bawah $0,1 \mathrm{~m}$ dan keempat sisi samping dinding $0,1 \mathrm{~m}$. Total volume ruang kosong ini adalah $31,2 \mathrm{~m}^{3}$.

Tabel 1. Volume bagian-bagian cold storage

\begin{tabular}{clc}
\hline No & \multicolumn{1}{c}{ Jenis Bagian } & Volume $\left(\mathrm{m}^{3}\right)$ \\
\hline 1 & Ante room & 6,0 \\
2 & Fan evaporator & 3,9 \\
3 & Sisi atas, bawah dan & 31,2 \\
& keempat samping & \\
& dinding & \\
\hline & Total & 41,1 \\
\hline
\end{tabular}

Volume cold storage yang dapat digunakan untuk penyimpanan produk adalah selisih dari volume cold storage keseluruhan dengan bagian cold storage untuk konstruksi dan peralatan, yakni $288-41,1=246,9 \mathrm{~m}^{3}$. Untuk dos yang digunakan dengan ukuran $\mathrm{p}=0,5 \mathrm{~m}, 1=0,35 \mathrm{~m}$, dan $\mathrm{t}=0,1$ $\mathrm{m}$, dengan volume $0,02 \mathrm{~m}^{3}$, maka jumlah dos yang dapat disimpan adalah $246,9 \mathrm{~m}^{3} / 0,02 \mathrm{~m}^{3}=12.344$ dos. Jika setiap dos memiliki berat $10 \mathrm{~kg}$, maka kapasitas cold storage, yaitu jumlah dos dalam cold storage kali berat tiap dos adalah $12.344 \times 10$ $\mathrm{kg}=123.440 \mathrm{~kg}=123,44$ ton.

\section{Perhitungan beban pendingin cold storage}

Beban pendingin cold storage adalah jumlah panas yang harus dikeluarkan atau diserap oleh bahan pendingin (refrigeran) dari ruangan sehingga suhu ruangan yang diinginkan dapat tercapai (Arismunandar dan Saito. 2005). Dalam perhitungan ini beban pendingin yang dihitung terdiri dari beban pendingin dari luar cold storage yang terdiri dari beban pendingin akibat rembesan panas melalui dinding, atap dan lantai cold storage; dan beban pendingin dari dalam cold storage yang terdiri dari panas produk, panas pekerja, panas dari lampu/penerangan, panas dari pemanas pada evaporator saat melakukan defrost dan panas dari kipas evaporator. Untuk harga konduktivitas termal bahan dan koefisien konveksi dinding sebagai berikut:
Tabel 2. Konduktivitas termal (k) dan koefisien konveksi (f)

\begin{tabular}{ccc}
\hline No & Bahan dan Dinding & Btu \\
\cline { 3 - 3 } $\mathrm{ft}^{2} \cdot{ }^{\circ} \mathrm{F} . \mathrm{hr}$ \\
\hline & Konduktivitas termal bahan & \\
1 & Bata + plesteran & 5,0 \\
2 & Polyurethane foam & 0,17 \\
3 & Stainless steel & 130 \\
& Konveksi permukaan dinding & \\
4 & Bagian luar $\left(\mathrm{f}_{\mathrm{o}}\right)$ & 6,0 \\
5 & Bagian luar $\left(\mathrm{f}_{1}\right)$ & 1,65 \\
\hline
\end{tabular}

Perhitungan beban pendingin dari luar cold storage

Beban pendingin dari luar berasal dari rembesan panas melalui dinding, atap dan lantai.

1. Rembesan panas melalui dinding Untuk luas 4 (empat) sisi dinding $\left(\mathrm{A}_{\mathrm{d}}\right)$ : $\mathrm{A}_{\mathrm{d}}=[(12 \times 3)+(8 \times 3)+\{(12-1) \times 3\}+\{(8-2) \times 3\}] \mathrm{m}^{2}$ $=111 \mathrm{~m}^{2}=1194,79 \mathrm{ft}^{2}$

Tabel 3. Jenis lapisan dan ketebalan dinding cold storage

\begin{tabular}{clc}
\hline No & \multicolumn{1}{c}{ Jenis Lapisan } & Tebal (in) \\
\hline 1. & Stainless steel $\mathrm{I}\left(\mathrm{X}_{1}\right)$ & 0,02 \\
2. & Polyurethane foam $\left(\mathrm{X}_{2}\right)$ & 5,91 \\
3. & Stainless steel II $\left(\mathrm{X}_{3}\right)$ & 0,02 \\
\hline
\end{tabular}

Koefisien perpindahan panas gabungan untuk dinding $\left(\mathrm{U}_{\mathrm{d}}\right)$ :

$U_{d}=\frac{l}{\frac{l}{f_{o}}+\frac{X_{1}}{k_{1}}+\frac{X_{2}}{k_{2}}+\frac{X_{3}}{k_{3}}+\frac{l}{f_{1}}}$

di mana faktor-faktor $X$ dan $k$ berturut-turut adalah ketebalan jenis lapisan dan konduktivitas termalnya.

$$
\begin{aligned}
U_{d} & =\frac{8}{\frac{8}{6,0}+\frac{0,02}{130}+\frac{5,91}{0.17}+\frac{0,02}{130}+\frac{8}{1,65}} \\
& =0,1954 \frac{\mathrm{Btu}}{\mathrm{f} \mathrm{t}^{2} \cdot{ }^{\circ} \cdot \mathrm{hr}}
\end{aligned}
$$

Beban panas melalui dinding $\left(\mathrm{H}_{\mathrm{d}}\right)$ dengan suhu luar $\left(\mathrm{t}_{\mathrm{o}}\right) 89,6^{\circ} \mathrm{F}$ dan suhu di dalam cold storage $\left(\mathrm{t}_{1}\right) 13^{\circ} \mathrm{F}$ adalah

$$
\begin{aligned}
\mathrm{H}_{\mathrm{d}} & =\mathrm{U}_{\mathrm{d}} \times \mathrm{A}_{\mathrm{d}} \times\left(\mathrm{t}_{\mathrm{o}}-\mathrm{t}_{\mathrm{i}}\right) \\
& =0,1954 \times 1194,79 \times(89,6-13) \mathrm{Btu} / \mathrm{hr} \\
& =23.953,19 \mathrm{Btu} / \mathrm{hr}
\end{aligned}
$$


2. Rembesan panas melalui atap

Untuk luas atap $\left(\mathrm{A}_{\mathrm{a}}\right)$

$$
\begin{aligned}
\mathrm{A}_{\mathrm{a}} & =[\{(1-2) \times \mathrm{p}\}+\{(\mathrm{p}-1) \times 2\}] \mathrm{m}^{2} \\
& =[\{(8-2) \times 12\}+\{(12-1) \times 2\}] \mathrm{m}^{2} \\
& =94 \mathrm{~m}^{2}=1011,80 \mathrm{ft}^{2}
\end{aligned}
$$

Untuk ketebalan tiap lapisan dinding dapat dilihat pada Tabel 3.

Koefisien perpindahan panas gabungan untuk $\operatorname{atap}\left(\mathrm{U}_{\mathrm{a}}\right)$ :

$$
\begin{aligned}
U_{a} & =\frac{l}{\frac{l}{f_{o}}+\frac{X 1}{k 1}+\frac{X 2}{k 2}+\frac{X 3}{k 3}+\frac{l}{f 1}} \\
U_{a} & =\frac{8}{\frac{8}{6,0}+\frac{0,02}{130}+\frac{5,91}{0.17}+\frac{0,02}{130}+\frac{8}{1,65}} \\
& =0,1954 \frac{\mathrm{Btu}}{\mathrm{f} \mathrm{t}^{2} \cdot{ }^{\circ} \cdot \mathrm{hr}}
\end{aligned}
$$

Beban panas melalui $\left(\mathrm{H}_{\mathrm{a}}\right)$

$$
\begin{aligned}
\mathrm{H}_{\mathrm{a}} & =\mathrm{Ua} \times \operatorname{Aa} \times\left(\mathrm{t}_{\mathrm{o}}-\mathrm{t}_{\mathrm{i}}\right) \\
& =0,1954 \times 1011,80 \times(89,6-13) \mathrm{Btu} / \mathrm{hr} \\
& =20284,60 \mathrm{Btu} / \mathrm{hr}
\end{aligned}
$$

Rembesan panas melalui lantai Untuk luas lantai $\left(\mathrm{A}_{1}\right)$

$$
\begin{aligned}
\mathrm{A}_{1} & =[\{(1-2) \times \mathrm{p}\}+\{(\mathrm{p}-1) \times 2\}] \mathrm{m}^{2} \\
& =[\{(8-2) \times 12\}+\{(12-1) \times 2\}] \mathrm{m}^{2} \\
& =94 \mathrm{~m}^{2}=1011,80 \mathrm{ft}^{2}
\end{aligned}
$$

Ketebalan beton cor adalah 5,91 in, sedangkan ketebalan dinding seperti pada Tabel 3. Koefisien perpindahan panas gabungan untuk lantai $\left(\mathrm{U}_{1}\right)$ :

$$
\begin{aligned}
U_{l} & =\frac{l}{\frac{l}{f_{o}}+\frac{X 1}{k 1}+\frac{X 2}{k 2}+\frac{X 3}{k 3}+\frac{X 4}{k 4}+\frac{l}{f 1}} \\
U_{l} & =\frac{8}{\frac{8}{6,0}+\frac{5,91}{12,0}+\frac{0,02}{130}+\frac{5,91}{0.17}+\frac{0,02}{130}+\frac{8}{1,65}} \\
& =0,19307 \frac{\mathrm{Btu}}{\mathrm{f} \mathrm{t}^{2} \cdot{ }^{\circ} \cdot \mathrm{hr}}
\end{aligned}
$$

Temperatur tanah diasumsikan sebagai temperatur rata-rata di luar ruangan dan di dalam ruangan sebesar $\mathrm{t}_{\mathrm{o}}=(32+(-25)) / 2=3,5{ }^{\circ} \mathrm{C}=38,3{ }^{\circ} \mathrm{F}$. Sehingga beban panas melalui lantai $\left(\mathrm{H}_{1}\right)$ adalah

$$
\begin{aligned}
\mathrm{H}_{1} & =\mathrm{U}_{1} \times \mathrm{A}_{1} \times\left(\mathrm{t}_{\mathrm{o}}-\mathrm{t}_{\mathrm{i}}\right) \\
& =[(0,19307) \times(1011,80) \times(38,3-13)] \mathrm{Btu} / \mathrm{hr} \\
& =10021,36 \mathrm{Btu} / \mathrm{hr} .
\end{aligned}
$$

Jumlah beban pendingin dari luar cold storage dapat dilihat pada Tabel 3.
Tabel 4. Beban pendinginan dari luar cold storage

\begin{tabular}{clc}
\hline No & \multicolumn{1}{c}{$\begin{array}{c}\text { Jenis Beban } \\
\text { Pendingin }\end{array}$} & $\begin{array}{c}\text { Besar Beban } \\
(\mathrm{Btu} / \mathrm{hr})\end{array}$ \\
\hline 1 & $\begin{array}{l}\text { Rembesan panas } \\
\text { melalui dinding }\end{array}$ & $23.953,19$ \\
2 & $\begin{array}{l}\text { Rembesan panas } \\
\text { melalui atap }\end{array}$ & $20.284,60$ \\
3 & $\begin{array}{l}\text { Rembesan panas } \\
\text { melalui lantai }\end{array}$ & $10.021,36$ \\
\hline Total & & $54.259,15$ \\
\hline
\end{tabular}

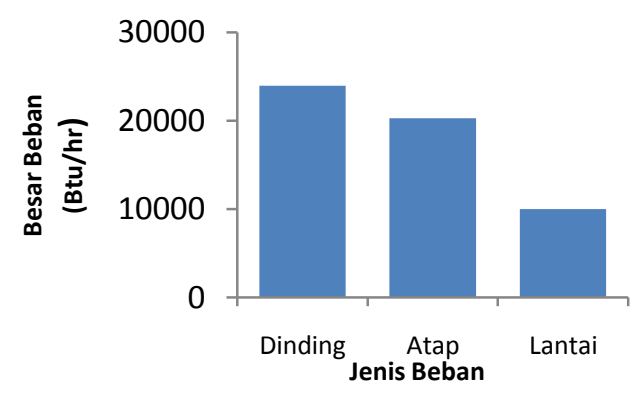

Gambar 2. Beban pendingin dari luar cold storage.

Perhitungan beban pendingin dari dalam cold storage

Beban pendingin dari dalam berasal dari panas produk, panas pekerja, panas lampu, panas dari kipas evaporator dan panas dari pemanas mesin pendingin. Panas dari produk merupakan panas yang berasal dari ikan yang disimpan dalam cold storage.

Berdasarkan data: massa produk (m) 1 ton/day (2240 lb/day), panas spesifik produk (cv) 0,45 $\mathrm{Btu} / \mathrm{lb}{ }^{\circ} \mathrm{F}$, temperatur awal produk $\left(\mathrm{t}_{\mathrm{P}}\right)-18{ }^{\circ} \mathrm{C} \quad(-$ $\left.0,4{ }^{\circ} \mathrm{F}\right)$, dan temperatur penyimpanan $\left(\mathrm{t}_{\mathrm{i}}\right)-25{ }^{\circ} \mathrm{C}(-$ $\left.13{ }^{\circ} \mathrm{F}\right)$, maka panas dari produk $\left(\mathrm{H}_{\mathrm{s}}\right)$ adalah

$$
\begin{aligned}
\mathrm{H}_{\mathrm{s}} & =\mathrm{m} \times \operatorname{cv} \times\left(\mathrm{t}_{\mathrm{p}}-\mathrm{t}_{\mathrm{i}}\right) \\
& =[2240 \times 0,45 \times\{(-0,4)-(-13)\}] \text { Btu/day } \\
& =12.7008 \text { Btu/day }
\end{aligned}
$$

atau untuk satu jam $\mathrm{H}_{\mathrm{s}}=5292 \mathrm{Btu} / \mathrm{hr}$.

Panas dari pekerja merupakan panas yang dikeluarkan oleh pekerja selama berada dalam cold storage. Dengan jumlah pekerja tujuh orang diasumsikan berada di dalam cold storage dengan jumlah waktu 10 jam sehari. Faktor beban panas dari orang yang bekerja dalam ruang pembeku (infreezers) adalah $1300 \mathrm{Btu} / \mathrm{hr}$, maka beban pendingin dari pekerja adalah: $\mathrm{H}=[7 \times 1300 \times(10 / 24] \mathrm{Btu} / \mathrm{hr}$

$$
=3791,67 \mathrm{Btu} / \mathrm{hr} \text {. }
$$


Panas dari lampu merupakan panas yang dikeluarkan oleh lampu selama dihidupkan. Terdiri atas 12 buah lampu pijar dengan daya masing-masing 60 watt. Lampu hanya dipasang pada saat pekerja dalam cold storage. Dengan faktor beban panas lampu sebesar 3,41 Btu/watt.hr, maka beban pendingin dari lampu adalah:

$$
\begin{aligned}
\mathrm{H} & =[12 \times 60 \times 3,41 \times(10 / 24)] \mathrm{Btu} / \mathrm{hr} \\
& =1023 \mathrm{Btu} / \mathrm{hr}
\end{aligned}
$$

Panas dari pemanas merupakan panas yang dikeluarkan oleh pemanas pada saat melakukan defrost dengan daya 24000 watt. Pemanas di PT. Sari Tuna Makmur tidak menggunakan motor listrik sehingga faktor beban panas electric motor tidak diperhitungkan. Dengan waktu operasi dari pemanas 2 jam sehari, maka beban pendingin dari pemanas adalah:

$$
\begin{aligned}
\mathrm{H} & =[24000 \times(2 / 24)] \mathrm{Watt} \times 3,413(\mathrm{Btu} / \mathrm{hr}) / \mathrm{Watt} \\
& =6826 \mathrm{Btu} / \mathrm{hr}
\end{aligned}
$$

Panas dari kipas evaporator merupakan panas yang dikeluarkan oleh kipas selama beroperasi. Kipas bekerja selama 22 jam sehari dengan daya 1500 watt dan faktor beban panas electric motor 3,415 Btu/watt.hr, maka beban pendingin dari kipas adalah:

$$
\begin{aligned}
\mathrm{H} & =1500 \times 3,415 \times 22 / 24 \\
& =4695,63 \mathrm{Btu} / \mathrm{hr}
\end{aligned}
$$

Tabel 5. Beban pendingin dari dalam cold storage

\begin{tabular}{cll}
\hline No & Jenis Beban Pendingin & $\begin{array}{c}\text { Besar Beban } \\
(\mathrm{Btu} / \mathrm{hr})\end{array}$ \\
\hline 1 & Panas produk (ikan) & 5292 \\
2 & Panas Pekerja & 3791,67 \\
3 & Panas Lampu & 1023 \\
4 & Panas Pemanas & 6826 \\
5 & Panas kipas evaporator & 4695,63 \\
\hline Total & & 21628,3 \\
\hline
\end{tabular}

Jumlah beban pendingin dari dalam cold storage dapat dilihat pada Tabel 5. Dengan demikian total beban pendingin adalah penjumlahan beban pendingin dari luar dan dari dalam sebesar 75.887,4 Btu/hr. Menggunakan faktor running time sebesar 1,09 (dari dasar teori), maka total beban pendingin menjadi:

$$
\mathrm{H}=1,09 \times 75.887,4 \mathrm{Btu} / \mathrm{hr}
$$$$
=82.717,3 \mathrm{Btu} / \mathrm{hr} \text {. }
$$

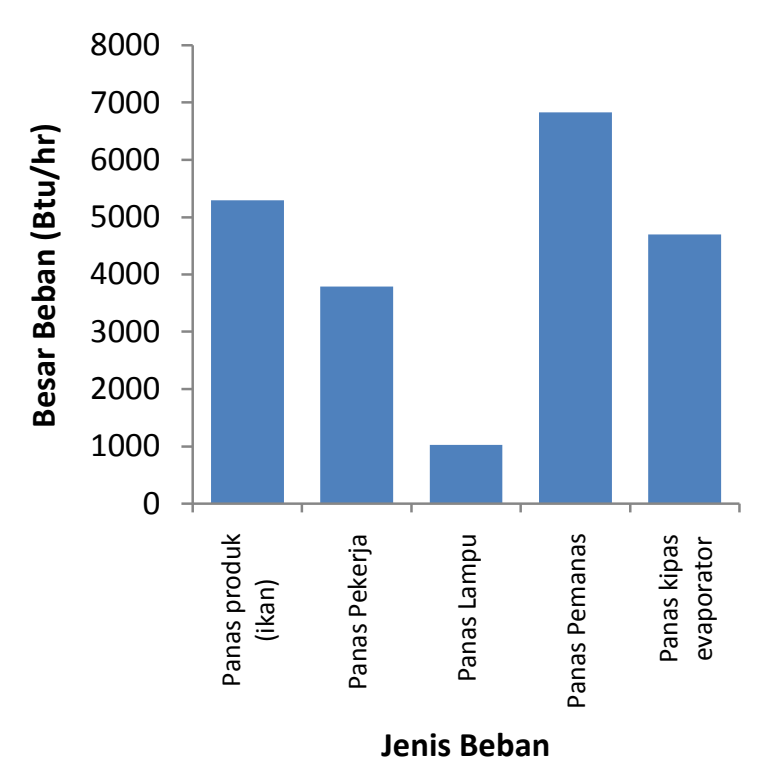

Gambar 3. Beban pendingin dari dalam coldstorage.

\section{KESIMPULAN}

Berdasarkan hasil perhitungan, didapat kesimpulan sebagai berikut: (1) Cold storage dapat menampung ikan beku sampai dengan 123,5 ton; (2) Beban pendingin cold storage adalah $82.717,32$ Btu/hr.

\section{DAFTAR PUSTAKA}

Afrianto, E. dan E. Liviawaty. 1992. Pengawetan dan Pengolahan Ikan. 1992. Unpad, Bandung.

Arismunandar, W. dan H. Saito. 2005. Penyegaran Udara. PT. Pradnya Paramitha, Jakarta.

Djojodiharjo, H. 1987. Termodinamika Teknik: Aplikasi dan Termodinamika Statistika. PT. Gramedia, Jakarta.

Hartanto, B. 1984. Mesin Pendinginan di Bidang Perikanan. Balai Keterampilan Penangkapan Ikan, Tegal.

Holman, J.P. 1986. Perpindahan Kalor. (Dialihbahasakan oleh E.Jasifi). Erlangga, Jakarta.

Karyanto, E. dan E. Paringga. 2004. Penuntun Praktikum Mesin Pendingin. Restu Agung, Jakarta.

Sofyan, I. 1983. Teknologi Refrigerasi Hasil Perikanan. Teknik Pendinginan Ikan. CV. Paripurna, Jakarta.

Stoecker. W.F. 1980. Refrigeration and Air Conditioning. Tata Mc-Graw Hill Publishing Company Ltd, New Dehli.

Sumanto dan Handoko. 1981. Dasar-Dasar Mesin Pendingin. Andi, Yogyakarta.

Sularso dan T. Haruo.1983. Pompa dan Kompresor. Pradnya Paramitha, Jakarta. 